The function $P(w)$ can also bo used to calculate the $R$-value which is to be expected when a part of the structure (for example, the heavy atoms alone) is used for calculating the $F_{c}$ 's. This follows from the relation:

$$
R=\frac{\Sigma|| F_{N}|-| F_{P}||}{\Sigma\left|F_{N}\right|}=\frac{-\int_{\infty}^{\infty}|w| P(w) \mathrm{d} w}{\int_{-}^{\infty} y P(y) \mathrm{d} y}
$$

where $P(y)$ is the distribution funotion for a single crystal (controsymmetric, or non-centrosymmetric, as the case may be), and is known. A table of $R$ as a function of $\sigma_{1}{ }^{2}$ has beon calculated for both the related and unrelated oases, and this has been found to be useful in cheoking whethor the positions of the heavy atoms determined are correct or not.

By calculating from $P(w)$ the intogral $P_{+}=\int_{0}^{\infty} P(w) \mathrm{d} w$, that is, the fraction of reflexions for which $w$ is positive, it is possible to put the intensity data of two isomorphous crystals on the same relative scale. The dotails are omitted.

Thus, those statistical mothods are found to have a number of applications to the study of isomorphous erystals. However, it may be mentioned that the foregoing results correspond only to the typo of isomorphism in which a small number of atoms aro added to a crystal. The extension of these studies to the case when the isomorphism is of the replacement type is possible and is under investigation.

G. N. Ramachandran

R. SRINIVASAN

Departmont of Physics,

University of Madras, India.

${ }^{1}$ Sutor, D. J., Acta Cryst., 11, 453 (1058).

${ }^{2}$ Sutor, D. J., Acta Cryst., 11, 83 (1958).

${ }^{3}$ Ramachandran, G. N., and Srinivasan, R., Acta Cryst., 12, 410 (1959).

\section{Crystallographic Data of Two Seleno-urea Derivatives}

As part of an investigation of the crystal structure of several derivatives of seleno-urea and a metal (palladium) the unit cell and space groups of $\alpha$-benzoyl $\beta$-phenyl selenourea and $\alpha$-acetyl $\beta$-phenyl seleno-urea have been determined.

(a) $\alpha$-benzoyl $\beta$-phenyl seleno-urea. Rotation and Woissenberg photographs, taken with copper $K \alpha$ radiation, showod that the unit coll is monoclinic with the dimensions: $a=19 \cdot 97 \pm 0 \cdot 03, b=5 \cdot 11 \pm 0 \cdot 03, c=13 \cdot 15 \pm 0 \cdot 03 \AA$, $\beta=104 \cdot 0 \pm 0 \cdot 3^{\circ}$

The space group is $P 2 / \mathrm{c}$. Tho observed density was $1.6 \mathrm{~g} / \mathrm{cm}^{3}$ in agreement with the calculated value 1.54 $\mathrm{g} / \mathrm{cm}^{3}$ corresponding to four molecules of $\alpha$-benzoyl $\beta$-phonyl seleno-urea per unit cell. The absorption coefficiont gavo $\mu=41.8 \mathrm{~cm}^{-1}$.

(b) $\alpha$-acetyl $\beta$-phenyl seleno-urea. Crystals are monoelinic with the dimensions: $a=10 \cdot 26 \pm 0.03, b=22.43$ $\pm 0.03, c=9 \cdot 36 \pm 0.03 \AA, \beta=113 \cdot 0 \pm 0.5^{\circ}$, deduced from rotation and Weissenborg photographs. Coppor $K \alpha$ radiation was used. The systematic absences are $0 k 0$ for $k$ odd and $h 0 l$ for $l$ odd, so that the spaco group is determined as $P 2_{1} / c$. The density measured by flotation is $1.7 \mathrm{~g} / \mathrm{cm}^{3}$. The calculated value for eight molecules per unit coll gives $1.69 \mathrm{~g} / \mathrm{cm}^{3}$. The absorption coefficiont for coppor $K \alpha$-radiation is $3.6 \mathrm{~cm}^{-1}$.

M. Pereaz Rovriguez

M. Cubero

A. Lopez Castro

Division de Ciencias dol C.S.I.C.,

Department of Physies,

University of Seville, Spain.

\section{CHEMISTRY}

\section{Detergent (Sodium Lauryl Sulphate)-splitting Enzyme from Bacteria}

THE persistonce of synthotic dotergent compounds in treated sowage effluents and rural water supplies has become an increasing problem ${ }^{1}$. Several investigations have been carriod out, using methylene blue colorimetrie and manometric techniques, of tho bio-dogradation of theso materials by the mixed bacterial flora in sewage and river water ${ }^{2}$. Payne and Feisal ${ }^{3}$ succeeded in isolating from benthonic soils two strains of bacteria, of which one could utilize lauryl sulphate and the othor both lauryl sulphate and alkyl benzonesulphonate as sole carbon sourcos. Investigation of dotorgent motabolism at tho enzyme-level has not yet been reported.

Alkyl benzene sulphonates constitute the major class of detergont in use for household purposes and, therefore, play the greatest part in water pollution problems. However, examination of the enzymatic degradation of those compounds is complicated by the onormous number of isomors to be considered. On tho other hand, alkyl sulphates are easily obtained in high purity without cross-contamination of isomors, inorganic sulphate, or other inorganic substances. By examining the mode of action of alkyl sulphate-destroying enzymes as a model, cluos might be obtained to facilitate investigation of enzymo action on alkyl benzene sulphonates. Becauso it is well known that detergents denaturo proteins, one wondors how a dotergent-destroying enzyme could escape denaturation. The investigation recorded here was initiated with thoso probloms in mind.

With synthotic minimal media containing sodium dodecyl sulphate (SDS) as both carbon and sulphur source, a gram-negative bacillus was isolated from raw sewage water of the 13altimore Back River Sewage 'Ireatment Plant. (As proposod by Schwatz and Powoy, the torm 'dodocyl' will be reserved for the true $\mathrm{C}_{12}$ radical, and the term 'lauryl' for the mixed aliphatic radicals (mainly $\mathrm{C}_{12}$ and $\mathrm{C}_{14}$ ) derived from coconut oil (Surface Active Agent, Interscience Publishers, Ine., Now York, 1949).) This strain could also utilize octyl, decyl, tetradocyl sulphate instead of dodecyl sulphate. (This serios of alkyl sulphate was kindly supplied ky Dr. R. C. Johnson of E. I. DuPont DeNemours and Co.)

Detergent utilization was assayed by non-polar complex formation of detergent with methylene blue via chloroform extraction 4 . As a product of onzyme activity, sulphate was measured with barium chloranilate ${ }^{5}$.

Bacteria wero grown at $37^{\circ} \mathrm{C}$ in the synthetic medium with sodium dodecyl sulphato as sole carbon and sulphur source. The cells wore collocted by centrifugation, washed with $0.14 \mathrm{M}$ sodium chloride solution and disrupted in a French pressure ecll ${ }^{6}$. All the detergent-splitting activity remained in the ultra-centrifugal supernatant $(110,000 \mathrm{~g}$ for $90 \mathrm{~min}$ ) and was not lost after dialysis. The enzyme preparation from colls adaptod to SDS roloased sulphato from decyl- and tetradecyl-sulphato as woll as SDS. That tho onzyme (or onzymes) is formed adaptively is suggested by the observation that the samo strain grown with citrate as carbon source did not yiold proparations with theso detergont-splitting activities. The same conclusion was reached in manometric assays using non-growing colls.

With SIS as substrate, the erude enzyme preparation consumed only $0.6 \mu \mathrm{M}$ oxygen during the release of 11.6 $\mu \mathrm{M}$ sulphate. This suggests that oxygen does not participate in the roloase of sulphate and that the enzyme action is the hydrolysis of the sulphate estor linkage; the other product of this type of reaction would be dodocyl alcohol.

Whon the concentration of SDS exceeded $6.7 \times 10^{-3} \mathrm{M}$, enzymo activity was lost. However, addition of bovine serum albumin permitted active hydrolysis of SDS at 